\title{
Objectivism, Relativism and the Importance of Rhetoric for Marxist Economics
}

\author{
William S. Milberg \\ Bruce A. Pietrykowski
}

\begin{abstract}
The revolution in social thought which has taken place in anthropology, sociology, history, literature and even law has been squelched in economics by both neoclassicals and Marxists. It is the purpose of this essay to show that aspects of contemporary poststructuralist and feminist theory are considerably more compatible with Marxian and neo-Marxian theory than with neoclassical thought. More important, we argue that these poststructuralist and feminist approaches, and especially their implicit theory of the relation between the individual and society, can significantly enhance Marxian economic analysis of the production process and consumer behavior by creating a richer theory of individual behavior and by expanding the Marxian conception of institutions and thus of accumulation and reproduction.
\end{abstract}

"One does not have to argue the reality of history: necessity ... does that for us. [W] hat can be added, however, is the proviso that history is inaccessible to us except in textual form, or in other words that it can be approached only by way of prior retextualization."

- Fredric Jameson (1982L: 82)

Poststructuralism makes strange bedfellows. The revolution in social thought which has taken place in anthropology, sociology, history, literature and even law has been squelched in economics by both

Graduate Faculty Economics Department, New School for Social Research, 65 Fifth Avenue, New York, NY 10003 and Department of Social Sciences, University of Michigan - Dearborn, Dearborn, MI 48128.

We are particularly grateful to Frank Thompson for detailed comments on earlier versions of the paper. Thanks also to Jack Amariglio, John Beverly, Sam Bowles, Robert Heilbroner, Hedy Kalikoff, David Levine, Adam Lutzker, Fred Moseley and participants in the URPE at ASSA session, "The Rhetoric of Economics: Marxist and Feminist Perspectives" in Washington, D.C., December 28, 1990, for comments and suggestions on an earlier version of this paper. We alone are responsible for the views presented.

(6) 1993 Union for Radical Political Economics.

Published by Blackwell Publishers, 238 Main St., Cambridge, MA 02142, USA, and 108 Cowley Rd., Oxford, OX4 1JF, UK. 
neoclassicals and Marxists. It is the purpose of this essay to show that aspects of contemporary poststructuralist and feminist theory are considerably more compatible with Marxian and neo-Marxian theory than with neoclassical thought. More important, we argue that these poststructuralist and feminist approaches, and especially their implicit theory of the relation between the individual and society, can significantly enhance Marxian economic analysis of the production process and consumer behavior by creating a richer theory of individual behavior and by expanding the Marxian conception of institutions and thus of accumulation and reproduction.

Drawing on poststructuralist ideas from philosophy, literary theory and feminist theory, we present an alternative conception of the subject which is compatible with the traditional Marxian notion of the social construction of the individual but which rejects the absoluteness and objectivity of most Marxian approaches. The alternative - which we call transsubjectivity - focuses on the social construction of the subject as a process of mediation between self and "lifeworld." In this process the individual is constrained by social institutions, but these institutions and even their meaning are formed by individuals.

In Section II we briefly review conceptions of the subject in contemporary Marxian economics discourse. Section III describes the challenge poststructuralism poses to these various Marxian views. We then introduce the notion of transsubjectivity, based on work in phenomenology and feminist and literary theory. In Section IV we apply the concept of transsubjectivity to Marxian and neo-Marxian approaches to production and consumption. We conclude with a discussion of the general applicability of transsubjectivity to current Marxian economic analysis.

\section{THE CONCEPTION OF THE SUBJECT IN MARXIAN ECONOMIC DISCOURSE}

Differences among the various schools of contemporary economic thought are rooted in their respective conceptions of the subject, that is their different views of what gives an individual identity in the economy. Each conception dictates a particular proper scope for economic analysis, an appropriate methodology and method for the pursuit of knowledge and, specifically, a theory of value and growth. Even within Marxian economics, methodological differences are rooted in differences in the conception of the subject.

In contemporary Marxian economics discourse we can identify two fundamental and competing conceptions of the construction of the subject: objectivist and relativist. The objectivists, who make up the 
majority of American Marxian economists, view the individual as socially constructed, determined by a set of objective social relations. Philosopher Richard Bernstein (1983: 8-9) provides the following definition:

By "objectivism," I mean the basic conviction that there is or must be some permanent, ahistorical matrix or framework to which we can ultimately appeal in determining the nature of rationality, knowledge, truth, reality, goodness, or rightness. The objectivist maintains that unless we can ground philosophy, knowledge, or language in a rigorous manner we cannot avoid radical skepticism.

Bernstein points out that this definition is more general than some others. It includes "metaphysical realism," "the claim that there is a world of objective reality that exists independently of us and that has a determinate nature or essence that we can know," as well as the traditional subject/object distinction in metaphysics that "what is "out there' (objective) is presumed to be independent of us (subjects), and knowledge is achieved when a subject correctly mirrors or represents objective reality." 1 The objectivist view is in very close keeping with Marx, who understood economic consciousness as largely determined by objective relations and forces of production:

In the social production of their existence, men inevitably enter into definite relations, which are independent of their will, namely relations of production appropriate to a given stage in the development of their material forces of production.... The mode of production of material life conditions the general process of social, political and intellectual life (Marx 1981: 20-21).

Of course there are some important distinctions among American Marxist economists holding the objectivist view. Some are very strict about the economic determination of individual consciousness. In these versions, dynamics in the capitalist economy are driven largely by class struggle and competition among capitals. Increases in the organic composition of capital due to the movement of capitals and technical change lead to a falling rate of profit. $^{2}$ Implicitly such models deny any role for individual behavior. Individual consciousness is presumably determined entirely in relation to the means of production, that is by class relations. Behavior which belies the "interests" of an individual's class affiliation is attributed to false consciousness. ${ }^{3}$

Others in the objectivist school see the individual as a function of the "accumulation structure" that is the entire set of institutions (economic, 
political, military, social, cultural) which are established for perpetuating and expanding the role and power of the capitalist class. This institutional structure (to which belongs the structure of class struggle) is inherently dynamic in that over time the relationships which allowed for accumulation act to retard accumulation. Hence, capitalists are at first enabled and then constrained by the institutional arrangement within which they find themselves:

Investment in capitalist economies is mediated fundamentally by social (or institutional) forces, however - that is by factors external to individual capitalists that are determined by collective social activities (Gordon, Reich and Edwards 1982: 26).

Both these variants are objectivist in that they posit a set of objective social relations as determining individual consciousness. The role of the individual in the construction of this set of social relations is considered meaningless or simply unimportant. Individual agency drops out, in favor of a view of individual behavior as a function of the objective social conditions. ${ }^{4}$

Analytical Marxism also fits in the objectivist category. This methodological-individualist Marxism gives prominence to individual action, but such action is not considered socially determined. According to Elster (1985), individual behavior is inherently intentional and is the product of preferences, beliefs and emotions. Elster goes on to identify two processes whereby individuals come to hold the beliefs or entertain the preferences they have. The first psychic process stems from motives such as wishful thinking or attempts to reduce cognitive dissonance ("hot" mechanisms). In this way, members of a dominated class may well come to accept their status of powerlessness by constructing an image of the capitalist lifestyle as simultaneously involving emotional hardship concomitant with spectacular affluence. This "sour grapes," attitude shapes preferences which are, in turn, shaped to some extent by the limited range of opportunities available to members of the oppressed class. ${ }^{5}$ The second psychic process ("cold" mechanisms) results from rational calculus and the utilization of instrumental or strategic modes of logic and reasoning which may be subject to the fallacy of composition. In these cases the conditions which logically hold at the local level tend to be violated at the global level (Elster 1985: 19-20). Ultimately, the motivation for individual action lies in psychic processes internal to the individual.

Relativist Marxism, meanwhile, posits individual identity as overdetermined, that is determined by all political, economic and cultural forces simultaneously: 
Each aspect of society ... is dependent on all the other aspects. No event or aspect of a society is independent; nothing determines other things without itself being determined by them (Wolff and Resnick 1988: 21).

The relativist position is not only anti-economic determinism, but antiany sort of linear deterministic conception of individual consciousness. Amariglio and Callari (1989: 34), for example, state that, "[p]remised on a nondeterminist approach, our rendition of commodity fetishism depicts the social constitution of the individual as much a 'precondition' for commodity trade as an effect of this trade." Here, too, there is no lack of support from Marx's writings on the social nature of production and exchange:

Individuals producing in a society, and hence the socially determined production of individuals, is of course the starting point of departure ....

(Marx 1981: 188-189).

\section{RHETORIC AND THE TRANSSUBJECTIVE THEORY OF THE SUBJECT}

\section{Rhetoric versus Objectivism}

The notion of economics as rhetoric now has a strong following from a small group of economists representing the neoclassical, institutionalist, post-Keynesian and Marxian schools of thought. ${ }^{6}$ The primary claim of this group is that economic discourse is argument and its claim for validity (truth, scientificity) is dependent entirely on the persuasiveness of the argument. Put simply by McCloskey (1988: 277), "We have no way to get outside our own human conversations and get in the mind of God in order to tell whether such and such an argument is True." While the rhetoric approach threatens all schools of thought claiming scientific objectivity and theoretical superiority, Marxian economics is the area perhaps most fundamentally challenged by the rhetoric approach. In particular, the rhetoric approach puts into question the objectivism of the various non-relativist approaches to Marxian economic analysis. ${ }^{7}$

In denying the existence of an ultimate truth, the rhetoric approach puts into question the objectivity of, for example, the relations and forces of production, and thus their determining force, even in the "last instance." The assumption that there exists a distinct set of forces of production which, though influenced by is still distinct from, the relations of production is basic to the objectivist position within Marxian philosophy. This objectivist position in economics has been supported by the work of philosophers of science. ${ }^{8}$ Bhaskar (1990), for example, 
attempts to locate a materialist philosophy in preexisting social structures into which individual agents enter. These already-existing structures are both reproduced and transformed in actions undertaken by classes and individuals. Bhaskar terms his philosophical approach "critical realism." But Bhaskar's main antagonist is logical positivism. When he moves beyond a critique of positivism and attempts to constitute a theory different from other theories critical of positivism, the logical structure of critical realism is revealed:

On this approach, while social structures are dependent upon the consciousness which the agents who produce or transform them have, they are not reducible to this consciousness. Social practices are concept-dependent; but, contrary to the hermeneutical tradition in social science, they are not exhausted by their conceptual aspect. They always have a material dimension (4).

Bhaskar's position is put into question by the rhetoric approach. What are the boundaries between materiality and consciousness or conceptladenness? In other words how is this material bedrock understood except as socially defined, linguistically circumscribed and symbolically mediated? For example, if one wants to look at material relations by describing the patterns of ownership of the means of production, this very effort is imbricated in linguistic assumptions and taken-forgranteds. ${ }^{9}$

For Bhaskar there can be a "science" of the social because there is a material social reality that exists beyond the scope of the knowing agent. Yet, to the extent that the social "scientist" is engaged in a process of unmasking structures of power and oppression, the mode of discourse adopted in order to describe such structures of power may well be a vehicle for the perpetuation of yet a different form of power. In particular, social-scientific practice denies a voice to the very social agents who are subject to the techniques of power.

The critique of the idea of an objective set of social relations also implies a criticism of individualist Marxism. Individualist Marxism is a subset of objectivism in that it is based on a conception of an objective, external reality in which the individual acts. The important difference from the other objectivists is that for the individualists the subject is naturally, not socially, determined. Thus preferences are exogenous and not endogenous to human interaction. ${ }^{10}$

The fundamental challenge to Marxian discourse posed by the rhetoric approach is rooted in its philosophical foundations, and especially its conception of the subject. Much of the work on the rhetoric of economics, unfortunately, ignores the question of subjectivity raised by 
its conceptualization of meaning. ${ }^{11}$ To explore the implications of this challenge, we must go beyond the rhetoric of economics to its philosophical inspiration - "poststructuralism."

\section{Poststructuralism, Subjectivity and Transsubjectivity}

Poststructuralism refers to a wide variety of theoretical developments since the 1960s in literary criticism, philosophy and feminist theory which begin with a critique of the limiting nature of the binary oppositions of structuralism and of the certainty and ahistoricity of modernist conceptions of science, knowledge and the individual. ${ }^{12}$ Meaning and thus identity, in the poststucturalist view, is constructed in a social process which relies on the existing system of symbols. Knowledge is thus viewed as contingent, and inextricably linked to the pursuit of power. And power itself is analyzed as a self-subverting and diffused end. Grand narratives are ideological in that they seek to naturalize language and power relations.

To the extent that meaning, notions of truth and thus individual identity are considered socially constructed in poststructuralist thought, it is compatible with objectivist and relativist Marxian economic analysis and its emphasis on the endogenous nature of culture and consciousness, as discussed above. ${ }^{13}$ But for poststructuralism the sociality of culture and meaning is not rooted purely in the economic realm, but in language itself or, more generally, symbolic exchange. Meaning is created in relation to the entire system of words and symbols, that is, the semiotic system (Derrida 1976). Meaning is not due to any fixed relation between language (the words) and the "real world," rather "meaning is an endless chain of semiosis."14 The identity of the subject, or individual, does not exist in some a priori or objective sense, but is constituted in the signification process. The subject is never "fully" revealed, since the process of signification itself never has an ultimate truth or end. The subject is thus decentered:

it is an illusion for me to believe that I can ever be fully present to you in what I say or write, because to use signs at all entails that my meaning is always somehow dispersed, divided, never quite at one with myself. Not only my meaning, indeed, but me: since language is something I am made out of, rather than a convenient tool I use, the whole idea that I am a stable, unified entry must also be a fiction (Eagleton 1983: 130).

Poststructuralism thus focuses on the role of linguistic or, more generally, symbolic communication, in the formation of identity. Furthermore, poststructuralism is anti-humanist in its denial of a priori 
(natural) concepts of knowledge and its assertion that the construction process is complex, multidimensional and at times incoherent. Poststructuralists (and implicitly the rhetoric approach) reject the Enlightenment notion of absolute truth and of the objectively grounded subject, notions on which economic science, both Marxian and neoclassical, has been based. Foucault has linked this scientism and the objectivization of the subject to "the will to truth" which is basic to the modern epoch, or what he calls the modern "episteme." For Foucault, the subject is constructed as the outcome of the pursuit of knowledge, and this latter is necessarily based on power relations, since

there is no power relation without the correlative constitution of a field of knowledge, nor any knowledge that does not presuppose and constitute at the same time power relations (Foucault 1977b: 63).

Subjectivity is necessarily objectifying because it results from the "power and knowledge relations that invest human bodies and subjugate them by turning them into objects of knowledge" (Foucault 1977a: 28). Most important for Foucault is that this process is not explicitly due to the repressive features of power but is a process resulting from the power and knowledge struggles through which "a human being turns him - or herself into a subject" (Foucault 1982: 208). This process is the outcome of discursive practice. While it always involves power, such power is not synonymous with repression but is also productive:

We must cease once and for all to describe the effects of power in negative terms: it "excludes, " it "represses, " it "censors, " it "abstracts," it "masks, " it "conceals." In fact power produces; it produces realities; it produces domains of objects and rituals of truth (Foucault 1977a: 174).

The objectification of the subject, then, is hardly "scientific" in any pure sense but instead the outcome of a certain constellation of power relations. Scientificity, or "the will to truth," is for Foucault but one of three "modes of objectification through which human beings have been made subjects" (Smart 1988: 106). In this sense neither Marx nor the neoclassicals represent a break from the modern episteme of objectivized subjects, since both employ the modern "discursive rules of formation," that is they continue to place "Man" at the center of the analysis determinate, quantifiable and fixed. ${ }^{15}$

Foucault considers not only repressive and ideological institutions but (and especially in his later work) the ways in which individuals turn themselves into subjects, what Foucault calls "technologies of the self." 
Thus there is no final determinant of subjectivity, economic or otherwise, other than the discursive practices which result from power and knowledge pursuits. ${ }^{16}$ Ideology - that dimension of language which poses the discourse as universal, completely general, that is objective plays an important role in the construction of the subject. Ideology hides the particularity of the discourse and thus of its subject, that is it "suppresses the role of language in the construction of the subject" (Belsey 1980: 61). As a result, ideology serves to naturalize power.

A number of feminist theorists have provided a similar critique of modernist conceptions of science and the subject, and have perhaps gone furthest in developing an alternative conception. ${ }^{17}$ These feminist scholars have traditionally raised the issue of the particularity (especially maleness) of science and the traditional scientific conception of the subject. Sandra Harding's $(1987,1990)$ work on epistemology is particularly relevant here because of its explicit link of realism and domination. For Harding, the objectivity of science can only be asserted in an environment of domination:

only to the extent that one person or group can dominate the whole, can 'reality' appear to be governed by one set of rules or be constituted by one privileged set of social relations .... In contrast we can detect ("in reality"?) that at any moment in history there are many "subjugated knowledges" that conflict with, and are never reflected in, the dominant stories a culture tells about social life (Harding 1990: 188).

The emphasis on the exclusionary nature of the modernist or objectivized subject raises questions of what is being excluded, and how a nonexclusionary discourse would establish its claim to truth. On the first of these, there is significant agreement that the modernist subject represents a particularly white male position. On the second issue there is considerable disagreement among empiricists, standpoint theorists and poststructuralists. ${ }^{18}$ Of these different stances, the latter is of most interest to us here, since it is this group which calls for a new way of approaching the construction of the subject, "a more fluid model of subjectivity, in which we seek to understand how we struggle to become subjects and how we resist provided subjectivities in relation to the regulative power of modern social apparatuses" (Probyn 1990: 181, 182). ${ }^{19}$ This feminist view is thus consistent with that of Foucault in that the subject is not considered a fixed being, but is continually being created in the process of interaction with others. According to Joan Scott (1986: 38, 39), "the subject is in a constant process of construction."

We would argue, however, that subjectivity is not a totally diffused and undifferentiated process. Individuals are constituted and reconstituted 
within a specific set of social and cultural institutions and practices. These practices are the backdrop against which we form meaningful statements about a shared social world. We call this background of shared norms and accepted meanings the "lifeworld" of the subject.

The concept of the "lifeworld" (Lebenswelt) is used by Alfred Schutz and Thomas Luckmann (1973: 3-4) to describe the taken-for-granted aspects of the social world:

By the everyday life-world is to be understood that province of reality which the wide-awake and normal adult simply takes for granted in the attitude of common sense. By this taken-for-grantedness, we designate everything which we experience as unquestionable; every state of affairs is for us unproblematic until further notice.

The everyday lifeworld contains the unspoken and unrecognized:

Thus from the outset, my life-world is not my private world but, rather, is intersubjective... (Schutz and Luckmann 1973: 4).

The critical theory of Jurgen Habermas explicitly grounds the structure of the lifeworld in the forms of social interaction governed by discourse. ${ }^{20}$ Unlike Schutz, Habermas attempts to uncover the formation of the lifeworld in "the structures of linguistically generated intersubjectivity:"

The elements of the lifeworld with which we are naively familiar do not have the status of facts or norms or experiences concerning which speakers and hearers could, if necessary, come to some understanding (Habermas 1987: 130).

Within phenomenological social theory, the concept of the lifeworld has been used in order to highlight the inherently social nature of action. $\mathrm{We}$, in turn, wish to call attention to the specific process whereby subjects form their identity. The lifeworld constitutes the social context within which the subject is constituted (Rasmussen 1984).

The melding of postructuralism and phenomenology gives a "transsubjective" conception of meaning and understanding, focusing on the social construction of the subject as a process of mediation between self and "lifeworld." Subjectivity is a process, an ongoing one, of interaction among individuals in which power (in both the repressive and constructive senses) is inherent and in which interpretation is the only access to meaning. The individual is determined by social relations, but these relations themselves are a function of individual and social 
interpretation. Identity is contingent - not in the objectivist Marxian sense - but in the sense of its dependence on interpretation of social reality and thus symbolic exchange. Clearly, the transsubjective approach renders problematic the modernist subject of both neoclassical and objectivist Marxian theory, since it involves the rejection of the notion of an absolute, autonomous subject, and instead insists on the dialogical basis for individual identity. The point is that this alternative conception of the subject accounts for systematic exclusion and oppression based on domination and exploitation, but also considers the possibility of individual reaction and creativity. Marxist economics can benefit enormously by adopting such a conception, breaking out of the straightjacket of objectivism. We argue in the next section that this alternative conception of the subject can provide new insights to the Marxian theory of consumption and production.

\section{RETHINKING THE ANALYSIS OF PRODUCTION AND CONSUMPTION}

Transsubjectivity is not a new concept in the social sciences. Anthropologists, for example, have discussed it for years. ${ }^{21}$ In economics, however, such notions are rarely applied. In this section we outline the application of transsubjectivity to key areas of economics: production and consumption.

\section{Production: Critique of the SSA Analysis of Institutions}

An example of how transsubjectivity can enhance Marxian analysis is its application to the understanding of institutions. Institutions form the basis for the social structures of accumulation (SSA) presentation of 20th century capitalist economic history (Gordon 1980; Gordon, Edwards and Reich 1982; Bowles, Gordon and Weisskopf 1991). Profitability, expanded accumulation and capitalist growth and hegemony are hindered or sustained by the particular constellation of institutions that exist at any one time. The institutional environment might be taken to represent an updated version of Marx's property or social relations of production. In the classic Marxian theory of capitalist growth and development, the forces of production are fettered by archaic property relations (Marx 1981: 21). Similarly, the institutional environment defining capital-labor and capital-citizen relations act to maintain and then hinder the accumulation process (Gordon 1980; Kotz 1990).

The SSA approach provides a salutary counterpoise to both strict economic determinism on the one hand and strict methodological individualism on the other. As such it allows for the construction of an empirically based radical political economics. A limitation of the SSA 
approach, however, is its relatively undifferentiated analysis of those features of the capitalist socioeconomic formation which are labeled institutions. Are institutions of the same type as "capital," "labor" or "the state" or are institutions processes mediating, constraining, delimiting the forms of socially acceptable action between economic agents and groups? If, for example, institutions are not the same as capital or labor, then does one not need to develop an account of how agents understand the meaning of institutions and how social institutions are affected by the forms of discourse used to understand and describe the experiences people have in them? ${ }^{22}$

For example, an accord between capital and labor is seen to form the basis for the emergence of the U.S. postwar SSA. What was the particular institutional matrix shaping the accord? From the SSA perspective, the "capital-labor accord" emerged out of the growing recognition of unions as a viable form of collective action for workers vulnerable to ad hoc dismissal, deskilling and arbitrary and punitive wage cuts. Union organizing gained the status of a legal right with the passage and enforcement mechanisms contained within the National Labor Relations Act of 1935. The movement from militant labor organizations to quiescent partners in capitalist production came about through the purges of militants in the 1940s together with the passage of the Taft-Hartley Act (Bowles, Gordon and Weisskopf 1991). One other event that marked the consolidation of the capital-labor accord was the 1948 GM-UAW contract in which wage growth was tied to productivity growth and changes in the cost-of-living (Bowles, Gordon and Weisskopf 1988: 74; Gordon, Edwards and Reich 1982: 188). Hence, the rules of the game defining the conduct of capital and labor were established over a period of several years during the 1930s and 1940s. Yet, the institutional development of a predictable, rationalized system of collective bargaining over wages, benefits and shopfloor working conditions was the outcome of more localized struggles involving threats to property rights, the legal standing of a collective action on the part of the working class, and contested definitions of work and expectations over the appropriate form and content of compensation for work. As an example of the discursive practices utilized by workers in describing their jobs and the meaning given to the type of compensation expected from work, let us propose an examination of the degree and direction of diffusion of the capital-labor accord.

While it is true that Bowles, Gordon and Weisskopf speak of the "limited" capital-labor accord in that many workers were excluded, especially blacks and women workers, how quickly did the GM-UAW contract diffuse throughout the U.S. manufacturing sector? Which industries or workers did not readily participate in the accord and why? 
What were the local bargaining histories preceding the GM-UAW pact? To what extent did the extensive discussions and debates between the upper echelon of the unions and management which took place over the course of four weeks during Truman's Labor-Management Conference of 1948 establish a set of discursive practices different from those of the rank and file?

Answers to these questions would elucidate the as-yet unclear conceptual and historical status of the postwar capital-labor accord. We know, for example, that the $1948 \mathrm{GM}-\mathrm{UAW}$ agreement was looked upon with suspicion by the UAW. As Lichtenstein (1989: 14) notes, "Reuther himself rejected wage escalation until early 1948, and the Twentieth Century Fund survey of union leaders revealed that more than 90 percent opposed COLA clauses in their contracts." Pattern bargaining, the cornerstone of the accord to the extent that it ensured predictability and rationalized investment planning decisions, was limited to a few industries:

Beginning in 1946 there were four distinct collective bargaining "rounds" in which the wage pattern hammered out in the steel or auto industry became the standard applied in rubber, meatpacking, electrical products and other core industries... But this sort of pattern bargaining had a remarkably anemic life. It never spread much beyond the oligopolistically-structured core industries, and even there required a strong union... (1989: 144).

Did the rank and file come to view the wage bargain differently as a result of the events of the 1940s? Furthermore, how did union leaders feel about the growing standardization and rationalization of the labor market? Jacoby (1985), for instance, notes that union leaders feared that the imposition of general rules of the game would limit their discretion and their power.

If the productivity-wage bargain was emblematic of a new game of labor-management relations, how did the symbolic status of the wage change? Was the meaning of the wage the same for all workers regardless of differences in workers' union status, type of production technology employed, gender and race? Alice Kessler-Harris suggests that people endow the wage with symbolic meaning:

If the wage is, as most economists readily acknowledge, simultaneously a set of ideas about how people can and should live and a marker of social status, then it contains within it a set of social messages and a system of meanings that influence the way women and men behave (1990: 7). 
Seen from this perspective, the wage is internal to the social practices involving relations between labor and management as well as those practices and discourses about solidarity or dissension within the rank and file. A transsubjective interpretation of the capital-labor accord (and labor market activity in general) would provide a first step toward further understanding those institutional features of capital-labor relations uncovered by the SSA approach. ${ }^{23}$

\section{Consumption: the Formation of Preferences}

Transsubjectivity provides a new view of what a consumer is. It therefore necessarily implies a new view of the formulation of consumer preferences. While one of the underpinnings of neoclassical theory is the exogeneity of individual preferences, Marxian theory has always viewed preferences, and more generally individual consciousness, as endogenous to the economic system. Consumer preferences are a function of class identity and thus production relations. Worker consumption patterns, for example, are determined by the system's reproduction requirements, that is the subsistence needs in a given culture. ${ }^{24}$ More generally, according to Marx (1973: 92),

production produces consumption (1) by creating the material for it; (2) by determining the manner of consumption; and (3) by creating the products, initially posited as objects, in the form of a need felt by the consumer.

Marxist economics has tended to downplay the importance of consumption and preference formation. Still, the "realization problem" is of course key to underconsumptionist Marxism and recent developments of the classical theory of economic dynamics (Semmler 1990) have pointed to the role of consumption behavior and credit markets in macroeconomic instability.

Development of Marx's view, quoted above, has taken a liberal and radical tack. In the liberal view it is large corporations which impose artificial needs on consumers through advertising and careful marketing, what Galbraith (1970) calls "the dependence effect." In the more radical tack, this need creation is linked to capitalists' efforts to avoid a crisis from underconsumption (Baran 1957; Baran and Sweezy 1966). While these views certainly have some merit, they both tend to deny the role of the individual in preference formation, asserting instead the complete power of capital in forming consumer preferences (Matthei 1984: 87). This fails to account for the massive consumer surveys and market research that corporations undertake. Certain products are invented or rejected because of consumer behavior. More recently Matthei (1984) 
and Levine (1989) have tried to overcome these problems, calling for the reinclusion of individual choice in the context of a model in which the individual is socially determined. For Levine (1989: 32) this would be an attempt to "capture the liberal notion of agency within a framework of the social determination of persons." Matthei (1984: 87) seems to go even further: "The neoclassical conception of individual choice must be wedded to the Marxian conception of the social determination of the individual."

The transsubjective approach would encompass both a conception of individual choice and of social determination, without need for reversion to the liberalism of the natural (and exogenously given) individual of neoclassical theory. Autonomy does not exist in some absolute sense, but in the particular sense in which it is constructed transsubjectively. Individual choice could be analyzed as the outcome of the transsubjective process of individual formation. Individual identity is the result of particular psychological and anthropological and economic processes in which the individual participates and in which the individual gains identity.

The emphasis in a transsubjective approach would be on how consumption plays a role in the way the individual is created and on how the process of subjectivity affects preference formation. Consumption itself would be analyzed as one of the battlegrounds for the construction of the subject. This would involve removing the economically determined individual from his/her position as the starting point for theory and instead looking at how institutions - including discursive practices produce certain consumption patterns, especially through the exercise of power, exclusion and response.

Such an approach raises some new questions and potentially opens up a number of new areas for research on consumer behavior. First, our approach implies a study of preference formation as the outcome of the transsubjective process. This would require a study of preference formation among different groups, such as by gender, race and sexual orientation, in addition to class. In this sense, our approach opens up consumer research to previously excluded (and thus silent) groups. Feminist theory is particularly helpful here because of its focus on exclusion in the social construction of the subject and because, while the modernist subject is routinely figured as male, women have for over a century in the U.S. been the primary consumers. Second, our approach would require developing new categories of preference, to go beyond the rationality of preferences in neoclassical theory and the fixity of preferences in traditional Marxian theory. ${ }^{25} \mathrm{We}$ would be forced to account for "irrational" consumption behavior, for example that described in anthropological studies of gift giving by Sahlins (1972), 
Mauss (1989) and Battaille (1976). In addition, at the level of the lifeworld, studies of the motivation behind the practice of compulsive buying on the part of consumers find that the act of purchase rather than consumption plays a very important role in the creation of individuality. O'Guinn and Faber (1989) find that compulsive buyers tend to be less concerned with the object of purchase than are consumers in general. Rather, compulsive buyers seek the attention, recognition and esteem associated with the hierarchical relationship between customer and salesperson:

The gratifications received from this behavior were very frequently linked to the interpersonal contact, emotions, and positive self-esteem that were generated, rather than from anything derived from the product per se. In fact, informant comments suggest that the things purchased were often of little perceived utility after the purchase (154-155).

This observation suggests the need to present a more differentiated theory of preference formation in which subjects create their own identity through interaction with others rather than solely through their identification with commodities. ${ }^{26}$

The possibility of an independent role for the individual, irrespective of social class, is not a question of consumer sovereignty, which is simply a reflection of the liberal assumptions of neoclassical economics. The implication is that the conception of the market would be different, avoiding the reification of the concept of the market common to both neoclassical and Marxian theory. ${ }^{27}$ It requires coming to terms with the market as a social forum, not a natural equilibrating mechanism in which abstract capitals compete, eventually earning equal profit rates. There would be an emphasis on the power which comes with the knowledge of market research, marketing and pricing strategies in imperfectly competitive industries. But it would also focus on the consumer response and resistance to this repressive force. Individual preferences would be seen as social and evolving. Consumption patterns could be viewed as produced and producing (Smart 1988: 78). ${ }^{28}$

We have only very generally sketched the potential importance of transsubjectivity for understanding the process of endogenous preference formation. Perhaps most important, our approach indicates that such a process, with the individual autonomy it involves, is not only possible, but potentially an important element of the development of a Marxian understanding of modern capitalism. 


\section{CONCLUSION}

Contemporary Marxian economic theory, in its objectivist or relativist variant, does not yet provide a satisfactory account of the interaction between subjects and the social world. In particular, Marxist economics mired in an objectivist conception of the individual has resulted in an insufficient microeconomics - theory of institutions and individual consumer choice - and thus ultimately of markets and their evolution. Attempts to find the mechanism by which preferences are developed which involve a reduction of the process of individuation to a set of fixed determinants have the effect of fixing or objectifying the subject as well. But the fixed subject is illusory. And such a notion of the subject has the effect of excluding subjects which are different. Theories of determinate subjects are theories of dominant subjects or, at least, theories of undifferentiated subjectivity.

But a tradition so concerned with power, exploitation and revolution must be especially willing to scrutinize its own position. We have identified the strands of an alternative model of subjectivity in poststructuralist and feminist social theory. We suggest the notion of "transsubjectivity" to describe the process whereby individuals construct their identity through their interaction with others by interpreting the symbols and language of others.

At a minimum, we have tried to show that transsubjectivity is by no means inconsistent with Marxian economic analysis, but in fact can serve to enrich such analysis by introducing a more sophisticated notion of the socially constructed individual.

Marxist economists can use transsubjectivity to construct a description of the economic lifeworld - the unquestioned meanings and interpreted and accepted symbols of exchange, production and consumption. Such a project will potentially uncover the perspectives not discussed - the silent agents - in economic life. For example, we applied the concept of transsubjectivity to the theory of social structures of accumulation in order to expose some of the silent voices within the dominant capitallabor accord. We suggested that transsubjectivity provides a form of "deep" institutionalism which is currently lacking from the social structures of accumulation approach. A transsubjective theory of endogenous preferences would look to the process by which consumer identities are shaped and reshaped. Consumer identity is not an undifferentiated entity but rather a plurality of identifications made on the basis of gender, class, race and sexual orientation, as well as being influenced by the structure of production markets and technology. The discourse of consumer cultures is also a discourse of power wherein 
advertising and marketing act to create consumer identities which may be either adopted or resisted and challenged.

Marxist economists need to develop an account of the social construction of economic variables. What is the meaning of capital, labor, the wage and product innovation to actors located within a specific historical/institutional/symbolic matrix? How does the economist's interpretation differ from that of the social agent or class being studied? One means of uncovering this subtext of economic life would be to engage in local histories, descriptions of the ways in which structures or institutions are created and maintained or rejected at the micro-level. For instance, we might examine the way in which the micro-institutions of advertising and marketing influence the development of preferences and how subordinate subjects reconstruct meanings in their economic lifeworld.

The rhetoric of economics should not be so easily dismissed by Marxian and neo-Marxian economists. When the rhetoric of economics is read as a variant of poststructuralist and feminist theory in which power, domination, sameness and difference are key generative themes, we are then able to identify points of intersection with some of the major current issues of concern in Marxian and neo-Marxian economics.

\section{NOTES}

1. Objectivism is not to be defined specifically in terms of scientific realism. However, there are some similarities between the concepts. According to Boyd (1983), the philosophical discourse of scientific realism maintains, among other principles, that the historical progress of science is depicted by successive approximations to the true nature of both observable and unobservable phenomena and that "the reality which scientific theories describe is largely independent of our thoughts or theoretical commitments" (45). Following our criticism of objectivism, we argue that the "true" nature of phenomena is never absolutely attainable where the phenomena themselves are always the products of interpretive discourses and are socially constructed. For an example of this type of argument drawn from the philosophy of science, see Feyerabend (1978) on the early use of the telescope to ascertain the "true" nature of the universe.

2. For example, Mandel (1978: 39) maintains that the history of capitalism can be explained by the interplay of six variables: (1) the organic composition of capital; (2) the ratio of fixed to circulating capital; (3) the rate of surplus value; (4) the distribution of surplus between productive and unproductive consumption; (5) the turnover time of capital; and (6) exchange between Departments I and II. The kernel of objectivism is located in the totalizing nature of Mandel's theory. Nowhere is there any mention of how, for example, capital can be interpreted as a social phenomenon. Mandel assumes that there is an economic system "out there" that can be described and analyzed independently of the way of life of the particular individuals or groups of individuals participating in that system. For example, does 
the gender distribution of capital ownership make any difference to the way in which production is carried on, surplus extracted or turnover time shortened? This, we claim in Section IV, is not a trivial question.

3. This is not to say that objectivists do not have a concept of the subject. It is just that there is no creative role for the subject aside from the creation of obstacles to accumulation which capitalists must, and do, find ways to surmount. Shaikh (1978: 238), for example, allows worker opposition to affect the ability of capitalists to extend the working day. However, such autonomous working-class action is denied when capitalists shift toward increasing the rate of surplus value by increasing the division of labor and the rate of mechanization of the labor process; "Thus capitalists continually reduce the existing activities of living labor to mechanical forms." Shaikh fails to offer a treatment of how subjects form their own identity and to offer different interpretations of their experience of the mechanization process.

4. This view is implied in the work of the SSA school (e.g. Bowles, Gordon and Weisskopf 1991), although they do not explicitly discuss the determination of the individual. In an effort to clarify the methodological status of the SSA approach, Bowles, Gordon and Weisskopf (1988: 51) suggest that "one may take that set of institutionally determinate social relations as given historically; stipulate the relatively determinate interests which those social relations are likely to condition; trace the potential and actual conflicts of interest among constituent actors within the SSA which are engendered by those relations; and analyze how those resulting conflicts are mediated." Bowles and Gintis (1986: 96) have put forth a notion of subjectivity very close to the one we propose as an alternative in Section IV:

individual action is highly regulated - in a framework that insists that the historical dynamics of the structures regulating choice are themselves the result, however indirect and unintended, of individual action.

See also Bowles and Gintis (1986: 128 and 215, note 21). 'Unfortunately, this view of individual agency has not been reflected in Bowles' work on the SSA approach. For a relativist critique of Bowles and Gintis, see Cullenberg (1990). For more on the SSA school, see Section V below.

5. This range of opportunities could be explained by Roemer (1988) by reference to inequality in the initial distribution of physical assets.

6. Two collections of essays which contain views from each of these perspectives are Klamer et al. (1988) and Samuels (1990). McCloskey (1983) provided the initial inspiration to the discussion.

7. The response by Marxist economists to the rhetoric approach has been varied. Mostly it has been stiffly resisted, as nihilistic and dangerous for objective Marxian analysis. For more on the objectivist and relativist Marxian response to the rhetoric approach, and a non-overdeterminationist but anti-essentialist alternative, see Milberg (1991).

8. Bhaskar (1990) and Miller (1985, 1987). Miller offers a more general philosophical treatment of scientific realism. Bhaskar explicitly tries to locate his theory at the juncture of philosophy and political economy.

9. See Smart (1976). To see how an alternative conceptualization of the concept of capital might look, consider the well-known Marxian phrase that capitalists are the personification of capital. This phrase has always, to our knowledge, been taken to mean that capitalists stand in relation to or signify capital as its living representative. 
Yet, we argue that the very discussion of what counts as capital at any given moment can be radically reoriented if capital is seen to stand in relation to the capitalist. In this case those who are socially recognized and culturally defined as capitalists go about defining capital in relation to themselves. The status of capital is now constructed out of the social life of members of the capitalist class (financial capital, physical capital, fictitious capital can all be seen as the outcome of specific processes of interpretation and shared understandings of what counts as capital). Hence, capital becomes a tangible representation of the power of capitalists. Compare this to the traditional reading of Marx whereby capitalists are little more than automatons acting in the interest of capital.

10. For a more complete discussion of methodological individualism in its neoclassical variant, see Milberg (1988).

11. Klamer (1987: 83) criticizes McCloskey on precisely these grounds:

the metaphor of the rational individual ... is incommensurable with the metaphor of the rhetor which [McCloskey] develops in his book. The rhetor, namely, has to rely on conventions and rhetorical inventions instead of simple algorithms which the rational individual employs to calculate his optimal choice.

Lutzker (1992) pursues this point in some detail, arguing that McCloskey has a market theory of ideas and a Chicago theory of markets. One may accept the former and reject the latter.

12. Poststructuralist thought is far from monolithic. We ignore, for example, the apolitical analysis by the American deconstructionists such as Paul de Man, and focus instead on those poststructuralists whose ideas promote an extension of Marxian thought. The pioneer works of poststructuralist thought which inform our analysis include Derrida $(1976,1978)$, Lacan (1977), Foucault $(1970,1972)$, Jameson (1982) and Kristeva (1980). For excellent surveys of poststructuralism, see Eagleton (1983) and Norris (1981). Efforts to reconcile Marxism and poststructuralism (albeit from the perspective of literary criticism) include Frow (1986), Belsey (1980) and Ryan (1982).

13. See Eagleton (1976: Chapter 1) for a concise treatment of the objectivist Marxian conception of culture.

14. Frow (1986: 64). Poststructuralist theories of meaning are rooted in the semiotic analysis of Saussure (1986).

15. See Amariglio (1988), especially pages 593 and 609.

16. See Dews (1984) and Hartsock (1990) for critiques of Foucault's concept of power (and implicitly of subjectivity) from an objectivist Marxist perspective.

17. Probyn (1990: 178) in fact argues that the feminist critique of modernism is precisely what triggered the entire poststructuralist position. See Fraser and Nicholson (1989) for a review of the relationship between Lyotard's postmodernism and feminist theory.

18. For a review of these groups, see Di Stefano (1990) and Harding (1990). It should also be noted here that the relation between feminism and Marxism has been close yet problematic, what Heidi Hartmann has called "an unhappy marriage" (Hartmann 1981). This is not the place to take up in detail the efforts to link these two. Suffice it to say that feminist theorists have been divided between those who argue that the Marxian framework is adequate to capture the dynamic of exploitation of women (Hartsock 1990) and others who argue that the Marxian emphasis on class 
struggle ignores gender relations and thus is unable to account for, for example, oppression of women by men of the same economic class or within the family (Hartmann 1981, Folbre and Hartmann 1988).

19. Two critiques of this approach, which we call transsubjectivity, from within (broadly speaking) the poststructuralist school are Irigary (1987), for whom "[a]ny theory of the subject has already been appropriated by the masculine," and Spivak (1988), who asks "Why indeed should the subaltern [e.g., Third-World women] speak when she will only be rendered a native informant for first-world intellectuals interested in the voice of the other?"

20. Note that Habermas's theory of communicative action is not wholly compatible with the poststructuralist position. Habermas's theory does accept the legitimacy of statements made about an objective world. Also, Habermas conceives of power in terms of the ability of one agent to invoke claims to truth, sincerity and legitimacy without challenge. While this is not far from the "will to truth/power" position of Foucault (1980), Habermas explicitly seeks to retain the subject as a source for overcoming or countering the manifestations of power. See Dews (1984), Bernstein (1983) and Callinicos (1990).

21. See, for example, Geertz (1986).

22. Gordon, Edwards and Reich do attempt to distinguish between the inner and outer boundaries of a social structure of accumulation. The inner boundary includes within it the social, political, legal, cultural and market institutions thought to influence decisions to produce and invest. However, the desire to keep the activity of capitalists both distinct from the institutional environment yet also a reflection of that environment results in an underspecified model of institutional development, maintenance and change. It is important to point out that Bowles, Gordon and Weisskopf (1988: 51) have acknowledged this shortcoming as owing to the as yet incomplete nature of the SSA research project: "[W]e have not yet very closely explored the process of formation of the postwar SSA or other SSAs ... and must therefore treat the initial institutional conditions of the SSA as given, for the sake of this aspect of our analysis." While the proponents of the SSA approach appear quite conscious of the methodological problems involving the subject/object dichotomy, we maintain that institutions are themselves the outcome of a process of meaning interpretation within a differentiated social context and that attempts at understanding processes of institution formation may well yield historical interpretations not presently found within the SSA meta-narrative.

23. The transsubjective approach is consistent with Marx's own analysis in Capital, Volume 1, Chapter 10, of the conflict over competing definitions of the length of the working day. Marx's discussion of the Factory Acts, however, also suggests that the outcome of the social construction of the working day was determined in accordance with the "natural laws of the modern mode of production" (394). The work of E.P. Thompson (1971) on the resilience of community norms - constitutive of the English "moral economy" - in the face of a capitalist redefinition of a "fair price" emphasizes the contest over the meaning of economic variables in everyday life. Within this context, the approach we are suggesting moves further toward an understanding of how contested interpretations affect the constitution of subjectivity where the subject is more than a reflection of particular class-based interests. 
24. The neglect of consumer theory in Marxian economics may be due partly to this productionist orientation (Baudrillard 1976). Balbus (1982) claims that arguments framed in terms of the dominant mode of production are reductionist since they cannot account for the autonomous formation and display of domination emanating from the state or patriarchal structures.

25. Levine, for example, ultimately finds the Marxian conception to be similar to the neoclassical conception of purely exogenous preferences: "Marx and the classical economists allude to a social, cultural, and historical element in the determination of needs, but then proceed to treat needs as a fixed point both for the agent and for economic (and political) institutions. The treatment of want as something which emerges outside of economic and political life is common, then, to otherwise diverse interpretations of economy" (Levine 1989: 33).

26. Veblen (1931) hinted at such an idea.

27. For a critique of the neoclassical conception of the market, see Pietrykowski (1990). Regarding the classical conception, see Levine (1981).

28. A transsubjective approach to consumption behavior might also further our understanding of technological change. While the importance of demand in determining the rate and direction of technological innovation has been recognized for many years (Schmookler 1961, Rosenberg 1986), the transsubjectivity approach would potentially provide a mechanism to analyze the interaction of preference formation and product development.

\section{REFERENCES}

Amariglio, Jack. 1988. The Body, Economic Discourse, and Power: an Economist's Introduction to Foucault. History of Political Economy 20(4): 583-613.

Amariglio, J. and A. Callari. 1989. Marxian Value Theory and the Problem of the Subject: the role of Commodity Fetishism. Rethinking Marxism 2(3) Fall.

Balbus, Isaac D. 1982. Marxism and Domination. Princeton: Princeton University Press.

Baran, P. 1957. The Political Economy of Growth. New York: Monthly Review Press.

Baran, P. and Sweezy, P. 1966. Monopoly Capital. New York: Monthly Review Press.

Bataille, Georges. 1976. La Part Maudite, precede de la Notion de Depense. Paris: Editions de Minuit.

Baudrillard, Jean. 1976. The Mirror of Production. St. Louis: Telos Press.

Belsey, C. 1980. Critical Practice. London: Methuen.

Bernstein, R. 1983. Beyond Objectivism and Relativism. Philadelphia: University of Pennsylvania Press.

Bhaskar, Roy. 1990. Reclaiming Reality. London: Verso.

Bowles, Samuel and Herbert Gintis. 1986. Democracy and Capitalism. New York: Basic Books.

Bowles, Samuel, David M. Gordon and Thomas E. Weisskopf. 1986. Power and Profits: The Social Structure of Accumulation and the Profitability of the Postwar U.S. Economy. Review of Radical Political Economics 18(1 and 2) (Spring and Summer): 132-167.

Bowles, Samuel, David M. Gordon and Thomas E. Weisskopf. 1988. Social Institutions, Interests, and the Empirical Analysis of Accumulation: A Reply to Bruce Norton. Rethinking MARXISM 1(3) (Fall): 44-58.

Bowles, Samuel, David M. Gordon, Thomas E. Weisskopf 1991. After the Wasteland. Armonk, New York: M.E. Sharpe Publishers.

Boyd, Richard N. 1983. On the Current State of the Issue of Scientific Realism. Erkenntnis 19: 45-90.

Callinicos, Alex. 1990. Against Postmodernism: A Marxist Critique. New York: St. Martin's Press. 
Cullenberg, S. 1990. The Rhetoric of Marxian Microfoundations. Presented at the ASSA convention, Washington, D.C., December.

Derrida, Jacques. 1976. Of Grammatology. tr. Gayatri Chakrovorty Spivak. Baltimore: Johns Hopkins University Press.

Derrida, Jacques. 1978. Writing and Difference. tr. by Alan Bass. Chicago: University of Chicago Press.

Dews, Peter. 1984. Power and Subjectivity in Foucault. New Left Review 144 (March-April): 72-95.

Di Stefano, Christine. 1990. Dilemmas of Difference: Feminism, Modernity, and Postmodernism. In, Feminism/Postmodernism, L. Nicholson (ed.). New York: Routledge.

Eagleton, Terry. 1976. Marxism and Literary Criticism. Berkeley: University of California Press.

Eagleton, Terry. 1983. Literary Theory: An Introduction. Oxford: Basil Blackwell.

Elster, John. 1985. Making Sense of Marx. Cambridge: Cambridge University Press.

Feyerabend, Paul. 1978. Against Method. London: Verso.

Folbre, N. and H. Hartmann. 1988. The Rhetoric of Self-Interest: Ideology and Gender in Economic Theory, In, The Consequences of Economic Rhetoric. A. Klamer, et al. (eds.). Cambridge: Cambridge University Press.

Foucault, Michel. 1970. The Order of Things: An Archeology of the Human Sciences. London: Tavistock.

Foucault, Michel. 1972. The Archeology of Knowledge. tr. by A. M. Sheridan Smith. London: Tavistock.

Foucault, Michel. 1977a. Discipline and Punish: The Birth of the Prison. London: Penguin.

Foucault, Michel. 1977b. Nietzsche, Geneology, History. In, Language, Counter-Memory, Practice: Selected Essays and Interviews by Michel Foucault. D.F. Bouchard (ed.). Oxford: Blackwell.

Foucault, Michel. 1980. Power/Knowledge: Selected Interviews and Other Writings 1972-1977, C. Gordon (ed.). Brighton: Harvester Press.

Foucault, Michel. 1982. The Subject and Power. Afterward Dreyfus in H. Dreyfus, and P. Rabinow, Michel Foucault: Beyond Structuralism and Hermeneutics. Brighton: Harvester Press.

Fraser, Nancy and Linda Nicholson. 1989. Social Criticism Without Philosophy: An Encounter Between Feminism and Postmodernism. Social Text 7(3) (Winter): 83-104.

Frow, John. 1986. Marxism and Literary History. Cambridge, MA: Harvard University Press.

Galbraith, J.K. 1970. The Affluent Society. New York: New American Library.

Geertz, C. 1986. Works and Lives: the Anthropologist as Author. Stanford: Stanford University Press.

Gordon, David M. 1980. Stages of Accumulation and Long Cycles. In, Processes of the World System, Terrence Hopkins and Immanuel Wallerstein (eds.). pp. 9-45. Beverly Hills: Sage Publications.

Gordon, David M., Richard Edwards and Michael Reich. 1982. Segmented Work, Divided Workers: The Historical Transformation of Labor in the United States. Cambridge: Cambridge University Press.

Habermas, Jürgen. 1987. The Theory of Communicative Action. Volume 2. Boston: Beacon Press.

Harding, Sandra (ed.). 1987. Feminism and Methodology. Bloomington: Indiana University Press.

Harding, S. 1990. Feminism, Science and the Anti-Enlightenment Critiques. In, Feminism/Postmodernism. L. Nicholson, (ed.). New York: Routledge.

Hartmann, H. 1981. The Unhappy Marriage Between Marxism and Feminism. In, Women and Revolution, L. Sargent (ed.). Boston: South End Press.

Hartmann, Heidi. 1981. The Unhappy Marriage of Marxism and Feminism: Towards a More Progressive Union. In, Women and Revolution, L. Sargent (ed.). Boston: South End Press. 
Hartsock, Nancy. 1990. Foucault on Power: A Theory for Women? In, Feminism/ Postmodermism, Nicholson (ed.). pp. 157-175. New York: Routledge.

Irigary, L. 1987. Speculum of the Other Woman. Translated by Gillian Gill. Ithaca: Cornell University Press.

Jacoby, Stanford. 1985. Cost-of-Living Escalators Became Prevalent in the 1950's. Monthly Labor Review (May): 32-33.

Jameson, Fredric. 1982. The Political Unconscious: Narrative as Socially Symbolic Act. Ithaca: Cornell University Press.

Kessler-Harris, Alice. 1990. A Woman's Wage. Lexington: University of Kentucky Press.

Klamer, Arjo. 1987. Review of The Rhetoric of Economics. Review of Radical Political Economy 19 (Fall): 80-83.

Klamer, Arjo, D. McCloskey and R. Solow (eds.). 1988. The Consequences of Economic Rhetoric. Cambridge: Cambridge University Press.

Kotz, David M. 1990. A Comparative Analysis of the Theory of Regulation and the Social Structure of Accumulation Theory. Science and Society 54(1) (Spring 1990): 5-28.

Kristeva, Julia. 1984. Revolution in Poetic Language. Tr. by Margaret Waller. New York: Columbia University Press.

Lacan, Jacques. 1977. Ecrits. tr. by Alan Sheridan. London: Tavistock.

Levine, David. 1981. Economic Theory: Volume 2. London: Routledge \& Kegan Paul.

Levine, David. 1989. The Sense of Theory in Political Economy. Rethinking MARXISM 2(1): 29-48.

Lichtenstein, Nelson. 1989. From Corporatism to Collective Bargaining. In, The Rise and Fall of the New Deal Order, 1930-1980. Steve Fraser and Gary Gerstle (eds.). pp. 122-152. Princeton: Princeton University Press.

Lutzker, Adam. 1992. Rhetoric, History and Politics: The Social Production of Economic Knowledge. Mimeo, University of Michigan.

Lyotard, Francois. 1984. The Postmodern Condition: A Report on Knowledge. Tr. Geoff Bennington and Brian Massouri. Minneapolis: University of Minnesota Press.

Mandel, Ernest. 1978. Late Capitalism. London: Verso.

Marx, Karl. 1973. Grundrisse. New York: Vintage.

Marx, Karl. 1977. Capital, Volume 1. New York: Vintage.

Marx, Karl. 1981. A Contribution to the Critique of Political Economy, Maurice Dobb (ed.). New York: International Publishers.

Matthei, J. 1984. Rethinking Scarcity: Neoclassicism, NeoMalthusianism, and NeoMarxism. Review of Radical Political Economics 16 (Summer and Fall): 81-94.

Mauss, M. 1989. The Gift: the Form and Reason for Exchange in Archaic Societies. New York: Routledge.

McCloskey, Donald. 1983. The Rhetoric of Economics. Journal of Economic Literature 21: 481-517.

McCloskey, Donald. 1988. The Consequences of Economic Rhetoric. In, The Consequences of Economic Rhetoric. Klamer, Arjo, D. McCloskey and R. Solow (eds.). Cambridge: Cambridge University Press.

Milberg, W. 1988. The Language of Economics: Deconstructing the Neoclassical Text. Social Concept 4(2).

Milberg, W. 1991. Marxism, Poststructuralism and the Discourse of Economists. Rethinking Marxism 4(2).

Miller, Richard W. 1985. Analyzing Marx: Morality, Power and History. Princeton: Princeton University Press.

Miller, Richard W. 1987. Fact and Method: Explanation, Confirmation and Reality in the Natural and Social Sciences. Princeton: Princeton University Press.

Norris, Christopher. 1982. Deconstruction, Theory and Practice. London: Methuen.

O'Guinn, Thomas C. and Ronald J. Faber. Compulsive Buying: A Phenomenological Exploration. Journal of Consumer Research (September): 147-157. 
Pietrykowski, Bruce. 1990. Uncovering the Social Dimension of Market Exchange. Economics Working Paper \#63, Department of Social Sciences, University of Michigan - Dearborn.

Probyn, Elspeth. 1990. Travels in the Postmodern: Making Sense of the Local. In, Feminism/Postmodemism, L. Nicholson (ed.). New York: Routledge.

Rasmussen, David M. 1984. Explorations of the Lebenswelt: Reflections on Schutz and Habermas. Human Studies 7: 127-132.

Resnick, Stephen and Richard Wolff. 1987. Knowledge and Class: A Marxian Critique of Political Economy. Chicago: University of Chicago Press.

Roemer, John. 1988. Free to Lose. Cambridge: Harvard University Press.

Rosenberg, Nathan. 1982. Inside the Black Box: Technology and Economics. Cambridge: Cambridge University Press.

Ryan, Michael. 1982. Marxism and Deconstruction: A Critical Articulation. Baltimore: Johns Hopkins Press.

Sahlins, Marshall. 1972. Stone Age Economics. Chicago: Aldine Atherton.

Samuels, Warren J. 1990. Economics as Discourse: An Analysis of the Language of Economists. Boston: Kluwer Academic.

Saussure, Ferdinand de. 1986. Course in General Linguistics. LaSalle, Ill.: Open Court Press. Schmookler, J. 1961. Inventions and Economics Growth. Cambridge: Harvard University Press.

Schutz, Alfred and Thomas Luckmann. 1973. The Structures of the Lifeworld. Evanston: Northwestern University Press.

Scott, J. 1986. Gender: A Useful Category of Historical Analysis. In, Gender and the Politics of History. New York: Columbia University Press.

Shaikh, Anwar. 1978. Political Economy and Capitalism: Notes on Dobb's Theory of Crisis. Cambridge Journal of Economics 2 (June): 233-251.

Smart, B. 1976. Sociology, Phenomenology and Marxian Analysis. London: Routledge \& Kegan Paul.

Smart, Barry. 1988. Michel Foucault. London: Routledge.

Spivak, G. 1988. Can the Subaltern Speak? In, Marxism and the Interpretation of Culture, C. Nelson and L. Grossberg (eds.). Urbana, Illinois: University of Illinois Press.

Thompson, E. P. 1971. The Moral Economy of the English Crowd in the Eighteenth Century. Past and Present 50 (February): 76-136.

Veblen, Thorstein. 1931. The Theory of the Leisure Class. New York: Random House.

Wolff, R. and S. Resnick. 1988. Economics: Marxian versus Neoclassical. Baltimore: The Johns Hopkins University Press. 